\title{
IDENTIFIKASI KONSEP SUKAR, KESALAHAN KONSEP, DAN FAKTOR-FAKTOR PENYEBAB KESULITAN BELAJAR HIDROLISIS GARAM SISWA SALAH SATU SMA BLITAR
}

\author{
Galuh Febriani $^{* 1}$, Siti Marfu'ah ${ }^{2}$, Ridwan Joharmawan ${ }^{3}$ \\ Universitas Negeri Malang, Jalan Semarang Nomor 5
}

\begin{abstract}
Abstrak: Penelitian ini bertujuan mengidentifikasi konsep sukar, kesalahan konsep, dan faktor-faktor penyebab kesulitan belajar siswa pada materi hidrolisis garam. Penelitian ini bersifat deskriptif. Subjek penelitian yaitu seluruh siswa kelas XI MIA salah satu SMA Negeri di Blitar tahun ajaran 2017/2018. Instrumen penelitian berupa soal tes pilihan ganda beralasan dan angket. Hasil penelitian menunjukkan: (1) konsep sukar terbanyak dan terendah yang dimiliki siswa adalah 54 siswa terbanyak (86\%) tersedia pada konsep penentuan sifat ion dalam larutan dengan indikator analisis sifat kation dan anion dalam larutan berdasarkan harga $\mathrm{Ka}$ dan $\mathrm{Kb}$, dan 41 siswa terendah (65\%) terdapat pada konsep persamaan reaksi hidrolisis garam dengan indikator menentukan persamaan reaksi hidrolisis garam berdasarkan kekuatan asam atau basa penyusunnya. (2) Kesalahan konsep yang sering dialami siswa yaitu menganggap sifat ion sama dengan sifat zat asalnya, dan konversi satuan volume larutan kedalam liter dianggap tidak penting. (3) Faktor-faktor penyebab kesulitan mempelajari dan memahami materi hidrolisis garam adalah faktor internal yang sering dialami siswa yaitu kebiasaan belajar (pendisiplinan diri), sedangkan faktor eksternal yang sering dialami siswa yaitu penjelasan dan respon guru dalam proses pengajaran.
\end{abstract}

Kata kunci: Konsep Sukar, Kesalahan Konsep, Faktor-Faktor Penyebab Kesulitan Belajar, Hidrolisis Garam

\begin{abstract}
The purpose of this research was to identify the difficult concepts, misconception, and causative factors affecting the difficulty learning on salt hydrolysis topic among students in senior high school " $\mathrm{X}$ " Blitar. This research was descriptive research. The subjects of this research were all students of class XI Science Senior High School "X" in Blitar academic year 2017/2018. The research instruments are reasoned multiple choice and questionnaire form. The result shows that: (1) the highest and lowest difficult concept that students had were the 54 most students $(86 \%)$ that occur on the concept of determining ion properties in the solution with an indicator of the analysis of cation and anion properties in solution based on the value of $\mathrm{Ka}$ and $\mathrm{Kb}$, and 41 students with lowest score $(65 \%)$ are found in the concept of the salt hydrolysis reaction equation using indicator that determine the equation of the salt hydrolysis reaction based on the strength of the acid or base constituent. (2) Misconceptions that are often experienced by students are assuming the nature of the ion is the same as the nature of the substance of origin, and converting the unit of volume of the solution into the liter is considered unimportant. (3) Factors that cause difficulties in learning and understanding salt hydrolysis material are internal factors that are often experienced by students, namely learning habits (self-discipline), while external factors are often experienced by students, namely the explanation and response of the teacher in the teaching process.
\end{abstract}

Keywords: Difficult Concepts, Misconceptions, Factors Causing Learning Difficulties, Salt Hydrolysis

\section{PENDAHULUAN}

Pembelajaran merupakan salah satu proses dalam pendidikan, contohnya pembelajaran kimia. Pembelajaran kimia diantaranya menuntut siswa untuk dapat memahami konsep dengan benar, bukan sekedar memecahkan soal (Kean dan Middlecamp, 1985:6). Konsep kimia berjenjang dan saling berkaitan dari yang sederhana menuju ke konsep yang lebih kompleks (Sastrawijaya, 1998:178). Mempelajari konsep kimia yang lebih kompleks diperlukan pemahaman konsep fundamental. Sebagai contoh, hasil penelitian Wiyono (2011:62) memperoleh kesimpulan bahwa 
untuk mempelajari konsep hidrolisis diperlukan pemahaman konsep asam-basa Bronsted-Lowry yang benar. Konsep kimia juga memiliki karakteristik-karakteristik lain yaitu makna ganda yang dimiliki oleh suatu konsep, dan ada juga yang memiliki arti berlawanan. Contohnya, asam menurut Arhennius adalah zat yang terionisasi di dalam air membebaskan ion hidrgen $\left(\mathrm{H}^{+}\right)$sedangkan asam menurut Bronsted-Lowry adalah donor proton. Karakteristik-karakteristik konsep dalam ilmu kimia di atas memungkinkan untuk terjadinya kerancuan pemahaman atau pemahaman konsep secara tidak tepat oleh siswa (Effendy, 2002:9)

Kesukaran siswa dalam mempelajari kimia, diakibatkan karena kesukaran memahami konsep dengan benar sehingga konsep tersebut merupakan konsep sukar bagi siswa. Kesukaran, ketidakpahaman, atau timbulnya konsep lain yang dibentuk oleh siswa dapat mengakibatkan kemungkinan mengalami kesalahan pemahaman. Kesalahan pemahaman yang berlangsung secara terus-menerus atau konsisten serta menunjukkan kesalahan dengan sumber-sumber tertentu menunjukkan bahwa siswa mengalami kesalahan konsep.

Quliyah (2012) dalam penelitiannya menyimpulkan bahwa siswa mengalami kesulitan dalam memahami konsep-konsep yang sukar, dan sebagian besar siswa bahkan mengalami kesalahan konsep. Lebih spesifik Seçken dan Alşan (2011:239) melaporkan bahwa siswa mengalami kesalahan konsep dalam menentukan ion yang mengalami hidrolisis. Penelitian tersebut menjadi indikator bahwa masih banyak siswa SMA yang mengalami kegagalan dalam memahami konsep hidrolisis garam.

Kesulitan siswa dalam mempelajari kimia disebabkan siswa tidak memiliki pemahaman yang tepat terhadap konsep dasar kimia. Siswa yang mengalami kesulitan dalam memahami konsep dasar akan mengalami kesulitan pula dalam mempelajari konsep lain yang berhubungan. Hal ini diperkuat oleh penelitian Irawati (2010) yang menyatakan bahwa terdapat hubungan yang kuat antara konsep asam-basa Bronsted-Lowry dengan konsep hidrolisis. Materi asam-basa Bronsted-Lowry ini bertindak sebagai materi prasyarat untuk memahami materi hidrolisis garam sehingga siswa yang belum menguasai materi asam-basa Bronsted-Lowry dengan baik, kemungkinan besar akan megalami kesulitan dalam memahami materi hidrolisis garam. Selain itu, konsep hidrolisis juga harus dipahami dengan benar karena akan digunakan untuk mempelajari konsep kimia berikutnya, yaitu titrasi asam-basa.

Mengidentifikasi konsep sukar dan kesalahan konsep siswa, tentunya sangat penting untuk mengidentifikasi pula faktor-faktor yang mempengaruhi siswa mengalami kesulitan belajar. Kesulitan-kesulitan yang dialami oleh siswa pasti memiliki penyebab sehingga perlu diidentifikasi faktor-faktor yang mempengaruhi kesulitan-kesulitan tersebut agar segera diberikan bantuan untuk mengatasi kesulitan tersebut. Hal ini mendorong peneliti untuk mengetahui konsep manakah yang tergolong sukar dan kesalahan konsep serta faktor-faktor penyebab kesulitan belajar yang timbul pada materi hidrolisis garam. 


\section{METODE}

Penelitian ini merupakan penelitian deskriptif. Populasi dalam penelitian ini adalah siswa kelas XI MIA salah satu SMA Negeri di Blitar tahun ajaran 2017/2018 yang terdiri dari 160 siswa. Sampel penelitian ini adalah siswa kelas XI MIA 2 dan XI MIA 4 salah satu SMA Negeri di Blitar dengan jumlah siswa sebanyak 63 yang dipilih dengan teknik simple random sampling. Instrumen yang digunakan berupa soal pilihan ganda beralasan dengan 5 alternatif pilihan jawaban untuk menentukan persepsi konsep sukar dan kesalahan konsep. Sedangkan untuk menentukan faktorfaktor penyebab kesulitan belajar menggunakan instrumen angket. Instrumen tes ini memiliki validitas isi sebesar 90,00\% (soal); 83,34\% (angket) dan reliabilitas sebesar 0,849 (soal); 0,743 (angket) artinya reliabilitas tinggi.

Tahap analisis data pada penelitian ini dilakukan dengan tahap-tahap: (1) memberikan skor pada setiap soal tes yang dilakukan dengan mengoreksi jawaban siswa; (2) menghitung persentase siswa yang menjawab salah pada tiap butir soal untuk menentukan konsep sukar dengan kriteria persentase jawaban salah $\geq 61 \%$; (3) menghitung persentase tiap pengecoh yang dipilih oleh siswa pada soal; (4) menentukan kesalahan konsep berdasarkan kekonsistenan siswa yang diukur dari hasil tes dan wawancara jawaban yang mengandung konsep sama namun ditampilkan pada pengecoh dalam model soal yang berbeda; (5) menganalisis jumlah siswa yang memilih setiap skala untuk menentukan faktor-faktor penyebab kesulitan belajar dengan cara menghitung persentase jawaban siswa untuk masing-masing pilihan jawaban setuju dan tidak setuju.

\section{HASIL DAN PEMBAHASAN}

\section{Konsep Sukar dari Persentase Jawaban Salah (PJS) Siswa pada Konsep Hidrolisis Garam}

Data konsep sukar yang dimiliki siswa berupa persentase jawaban salah (PJS) pada konsep hidrolisis garam disajikan pada Tabel 1.

Tabel 1. PJS Konsep Hidrolisis Garam pada Siswa Kelas XI MIA

\begin{tabular}{|c|c|c|c|c|c|}
\hline No & Konsep & $\begin{array}{l}\text { No. } \\
\text { Soal }\end{array}$ & $\sum \mathbf{P D}$ & $\begin{array}{l}\sum \text { Jawaban } \\
\text { Salah PD }\end{array}$ & $\begin{array}{l}\text { PJS } \\
(\%)\end{array}$ \\
\hline 1 & Reaksi Asam Basa Bronsted-Lowry & & & & \\
\hline 1.1 & $\begin{array}{l}\text { Mengidentifikasi spesi yang bertindak sebagai } \\
\text { asam dan basa Bronsted-Lowry }\end{array}$ & 1 & 63 & 15 & 24 \\
\hline 2 & $\begin{array}{l}\text { Pengertian dan konsep umum hidrolisis } \\
\text { garam }\end{array}$ & & & & \\
\hline 2.1 & $\begin{array}{l}\text { Menjelaskan pengertian dan konsep umum } \\
\text { hidrolisis garam }\end{array}$ & 8 & 63 & 16 & 25 \\
\hline \multirow{3}{*}{2.2} & \multirow{3}{*}{ Mengidentifikasi reaksi hidrolisis garam } & 5 & 63 & 16 & 25 \\
\hline & & 10 & 63 & 29 & 46 \\
\hline & & 2 & 63 & 24 & 38 \\
\hline 3 & Penentuan sifat ion dalam larutan & & & & \\
\hline \multirow{2}{*}{3.1} & \multirow{2}{*}{$\begin{array}{l}\text { Menganalisis sifat kation dan anion dalam larutan } \\
\text { berdasarkan harga } \mathrm{Ka} \text { dan } \mathrm{Kb}\end{array}$} & 3 & 63 & 54 & 86 \\
\hline & & 6 & 63 & 46 & 73 \\
\hline
\end{tabular}




\section{Lanjutan Tabel 1.}

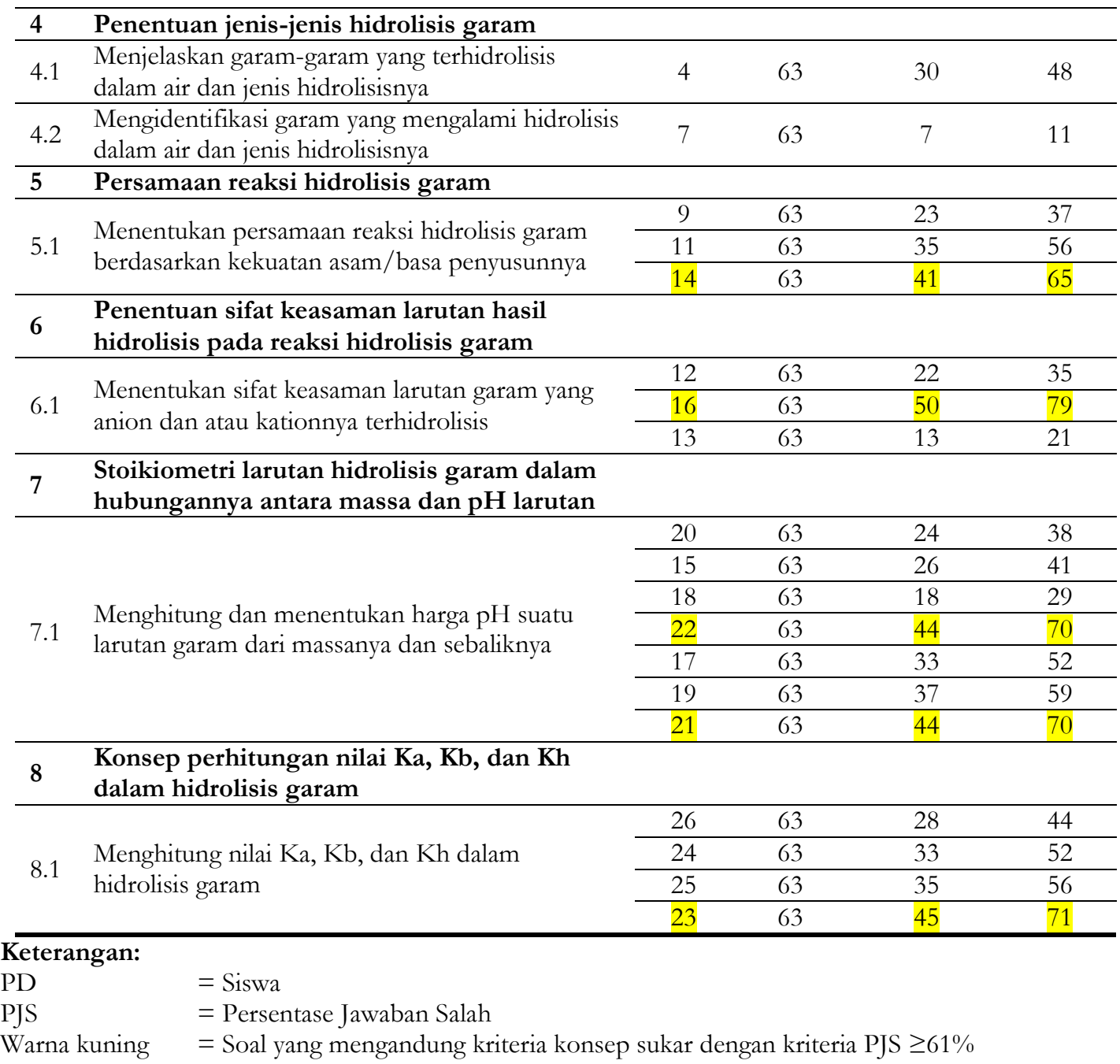

Tabel 1 menunjukkan bahwa kriteria PJS lebih dari atau sama dengan 61\% (Devinta dalam Ansori, 2015) merupakan konsep sukar siswa kelas XI MIA. Berdasarkan PJS yang dialami siswa pada Tabel 1 diperoleh grafik PJS pada Gambar 1. Soal nomor 3 merupakan soal dengan nilai PJS siswa terbesar yaitu $86 \%$. Soal tersebut merupakan soal yang sukar bagi siswa. Berdasarkan klasifikasi indeks kesukaran (P) nomor 3 memiliki nilai sebesar 0,14 yang artinya tergolong soal dengan kategori sukar. Sama halnya dengan soal nomor 16 merupakan soal dengan nilai PJS siswa terbesar kedua yaitu 78\%. Soal tersebut merupakan soal yang sukar bagi siswa. Berdasarkan klasifikasi indeks kesukaran (P) nomor 16 memiliki nilai sebesar 0,21 yang artinya tergolong soal dengan kategori sukar sehingga dapat disimpulkan terdapat hubungan yang linier antara persentase jawaban salah dengan indeks kesukaran soal. Selain itu juga disebabkan karena siswa tidak memahami dengan baik materi atau konsep-konsep prasayarat untuk mempelajari hidrolisis garam. 


\section{Grafik persentase jawaban salah}

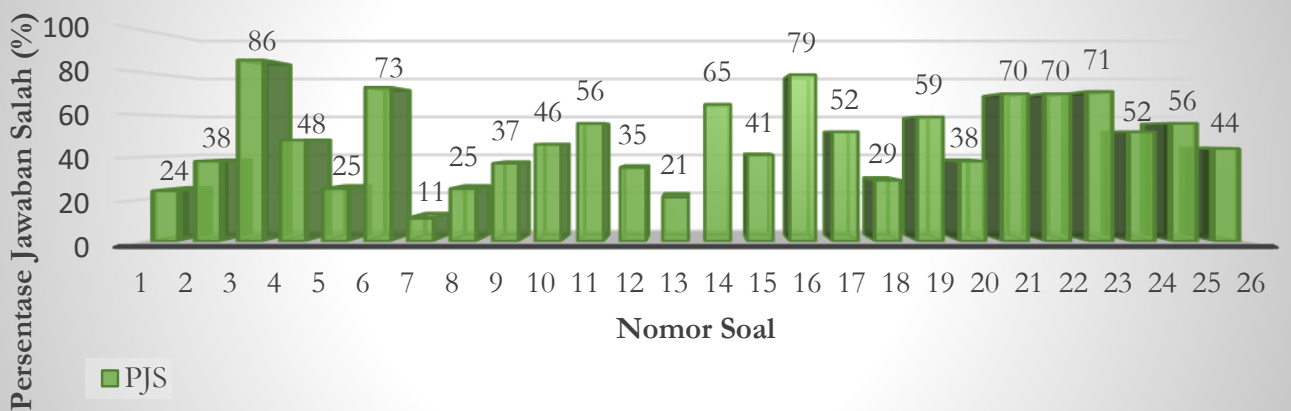

\section{Gambar 1. Grafik PJS Siswa Kelas XI MIA}

\section{Kesalahan Konsep Siswa Kelas XI MIA}

Kesalahan konsep yang dialami siswa dapat berasal dari konsep sukar dan konsep tidak sukar. Kesalahan konsep siswa kelas XI MIA diberikan pada Tabel 2.

Tabel 2. Kesalahan Konsep Hidrolisis Garam Pada Siswa Kelas XI MIA

\begin{tabular}{|c|c|c|c|c|c|}
\hline No & Kesalahan Konsep & Kekonsistenan Jawaban & $\mathbf{K}$ & $\sum \mathbf{P D}$ & $\begin{array}{l}\text { PK } \\
(\%)\end{array}$ \\
\hline 1 & $\begin{array}{l}\text { Menganggap ion yang berasal dari } \\
\text { basa lemah tidak mengalami } \\
\text { hidrolisis }\end{array}$ & $8 \mathrm{~B} / 8 \mathrm{D}, 5 \mathrm{~A} / 5 \mathrm{C}$ & 1 & 63 & 2 \\
\hline 2 & $\begin{array}{l}\text { Menganggap kation dari basa kuat } \\
\text { dapat bereaksi dengan molekul air }\end{array}$ & $2 \mathrm{D}, 11 \mathrm{~A}, 12 \mathrm{~B} / 12 \mathrm{D}$ & 1 & 63 & 2 \\
\hline 3 & $\begin{array}{l}\text { Menganggap kekuatan basa konjugat } \\
\text { sebanding dengan kekuatan asam }\end{array}$ & $3 \mathrm{~A}, 6 \mathrm{~B}$ & 2 & 63 & 3 \\
\hline 4 & $\begin{array}{l}\text { Menganggap kekuatan basa konjugat } \\
\text { tidak dapat ditentukan dari harga } \mathrm{Ka}\end{array}$ & $3 \mathrm{C}, 6 \mathrm{C}$ & 2 & 63 & 3 \\
\hline 5 & $\begin{array}{l}\text { Menganggap sifat ion sama dengan } \\
\text { sifat zat asalnya }\end{array}$ & $3 \mathrm{D}, 6 \mathrm{E}$ & 3 & 63 & 5 \\
\hline 6 & $\begin{array}{l}\text { Menganggap hidrolisis anion dari } \\
\text { asam lemah menghasilkan ion } \\
\mathrm{H}_{3} \mathrm{O}^{+} / \mathrm{H}^{+}\end{array}$ & $9 \mathrm{D} / 9 \mathrm{E}, 11 \mathrm{~B}, 12 \mathrm{~A}, 14 \mathrm{~B}$ & 1 & 63 & 2 \\
\hline 7 & $\begin{array}{l}\text { Tidak mengkonversikan satuan } \\
\text { volume larutan kedalam liter } \\
\text { sehingga mengakibatkan perhitungan } \\
\text { menentukan massa garam salah }\end{array}$ & 19C, 21C & 5 & 63 & 8 \\
\hline \multirow{3}{*}{8} & $\begin{array}{l}\text { Tidak memahami rumus tetapan } \\
\text { hidrolisis larutan garam yang berasal } \\
\text { dari asam lemah dan basa lemah, } \\
\text { yang seharusnya }\end{array}$ & \multirow{3}{*}{$23 \mathrm{C}, 25 \mathrm{D}$} & \multirow{3}{*}{2} & \multirow{3}{*}{63} & \multirow{3}{*}{3} \\
\hline & bukan $\quad \mathrm{Kh}=\frac{\mathrm{Kw}}{\mathrm{Ka} \times \mathrm{Kb}}$ & & & & \\
\hline & $\begin{array}{l}\qquad \mathrm{Kh}=\sqrt{\frac{\mathrm{Kw}}{\mathrm{Ka} \times \mathrm{Kb}}} \\
\text { sehingga mengakibatkan perhitungan } \\
\text { Kh garam salah. }\end{array}$ & & & & \\
\hline
\end{tabular}


Lanjutan Tabel 2

Tidak memahami rumus tetapan hidrolisis larutan garam yang berasal dari asam lemah dan basa lemah, yang seharusnya

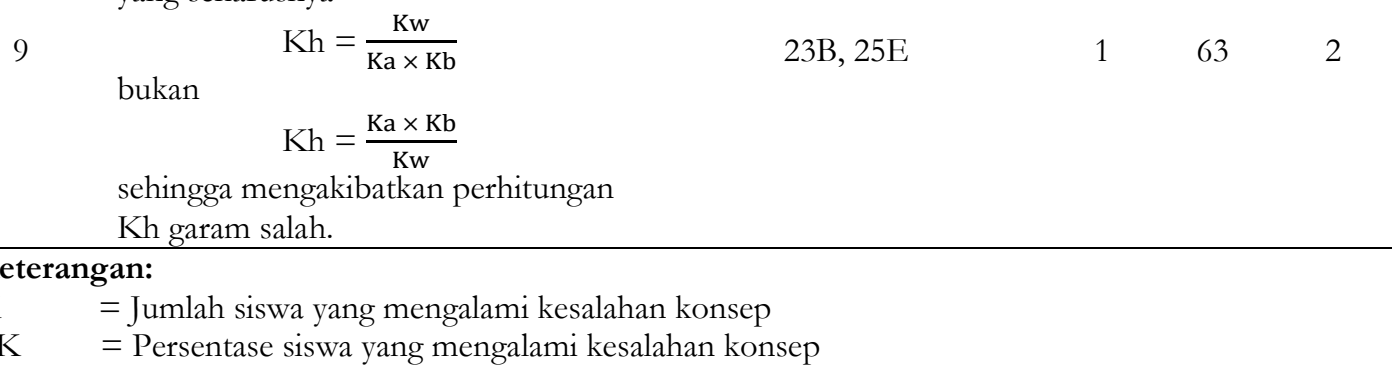

Data kesalahan konsep yang dialami siswa dapat berasal dari konsep sukar dan konsep tidak sukar. Kesalahan konsep siswa kelas XI MIA disajikan pada Tabel 2. Pada dasarnya penetapan siswa yang mengalami kesalahan konsep adalah bila siswa secara konsisten menjawab pilihan jawaban salah dengan konsep yang sama pada soal yang berbeda. Hal ini juga dipertegas dari hasil wawancara dengan siswa yang mengalami kesalahan konsep. Berdasarkan Tabel 2 kesalahan konsep siswa ditemukan pada konsep-konsep dengan kekonsistenan menjawab pilihan jawaban salah dan diperoleh 9 kesalahan konsep. Kesalahan konsep pertama yang paling banyak dialami siswa karena tidak mengkonversikan satuan volume larutan kedalam satuan liter sehingga mengakibatkan perhitungan salah. Hal ini menunjukkan siswa kurang teliti dalam soal yang megandung hitungan. Kesalahan konsep berikutnya diakibatkan menganggap sifat ion sama dengan sifat zat asalnya hal ini sesuai dengan hasil penelitian Seçken dan Alşan (2011) bahwa peserta didik mengalami kesukaran dalam menentukan sifat ion dalam larutan. Kegagalan dalam menentukan sifat ion ini menyebabkan peserta didik mengalami kesulitan mengidentifikasi ion yang mengalami hidrolisis.

\section{Faktor-faktor Penyebab Kesulitan Belajar Siswa dalam Memepelajari dan Memahami Materi Hidrolisis Garam}

Angket disebar pada dua kelas XI MIA, yakni kelas XI MIA 2 dan XI MIA 4. Dari jumlah total 63 angket yang disebar, diperoleh sebanyak 63 angket pula yang terisi. Jumlah angket yang disebar disesuaikan dengan jumlah siswa sebagai responden dari dua kelas yang diteliti. Kedua kelas tersebut merupakan sampel siswa kelas XI MIA yang telah menerima materi hidrolisis garam pada tahun 2017/2018 semester genap. Persentase faktor-faktor penyebab kesulitan siswa dalam memahami materi hidrolisis garam dapat dilihat pada Tabel 3.

Tabel 3. Persentase Faktor-Faktor Penyebab Kesulitan Belajar Siswa dalam Memahami Materi Hidrolisis Garam Kelas XI MIA

\begin{tabular}{|c|c|c|c|c|c|c|c|}
\hline \multirow{2}{*}{$\begin{array}{l}\text { Jenis } \\
\text { Faktor }\end{array}$} & \multirow[b]{2}{*}{ Indikator Penyebab Kesulitan } & \multicolumn{2}{|c|}{ No. Soal } & \multicolumn{2}{|c|}{ Setuju } & \multicolumn{2}{|c|}{ Tidak setuju } \\
\hline & & Positif & $\underset{f}{\text { Negati }}$ & $\sum_{\mathbf{P D}}$ & $\%$ PD & $\sum_{\mathbf{P D}}$ & $\% \mathrm{PD}$ \\
\hline \multirow{5}{*}{ Internal } & $\begin{array}{l}\text { Minat terhadap mata pelajaran } \\
\text { kimia khususunya pada materi } \\
\text { hidrolisis garam. }\end{array}$ & 1 & - & 17 & 26,98 & 6 & 9,52 \\
\hline & \multirow{4}{*}{$\begin{array}{l}\text { Menggali hasil belajar yang } \\
\text { tersimpan (kemampuan awal) }\end{array}$} & 2 & - & 12 & 19,05 & 8 & 12,70 \\
\hline & & 3 & - & 25 & 39,68 & 5 & 7,94 \\
\hline & & 4 & - & 22 & 34,92 & 7 & 11,11 \\
\hline & & 5 & - & 19 & 30,16 & 8 & 12,70 \\
\hline
\end{tabular}




\section{Lanjutan Tabel 3.}

\begin{tabular}{|c|c|c|c|c|c|c|c|}
\hline & & 6 & - & 24 & 38,10 & 4 & 6,35 \\
\hline & & 7 & - & 15 & 23,81 & 9 & 14,29 \\
\hline & \multirow{5}{*}{$\begin{array}{l}\text { Kemampuan dalam hitungan } \\
\text { (operasi matematis) }\end{array}$} & - & 8 & 16 & 25,40 & 14 & 22,22 \\
\hline & & - & 9 & 15 & 23,81 & 18 & 28,57 \\
\hline & & - & 10 & 15 & 23,81 & 13 & 20,63 \\
\hline & & - & 11 & 21 & 33,33 & 15 & 23,81 \\
\hline & & - & 19 & 15 & 23,81 & 17 & 26,98 \\
\hline & \multirow{3}{*}{$\begin{array}{l}\text { Kemampuan menentukan dan } \\
\text { menggunakan rumus kimia }\end{array}$} & - & 12 & 18 & 28,57 & 17 & 26,98 \\
\hline & & - & 13 & 20 & 31,75 & 18 & 28,57 \\
\hline & & $\begin{array}{lll}- & \\
\end{array}$ & 14 & 12 & 19,05 & 19 & 30,16 \\
\hline & \multirow{4}{*}{$\begin{array}{l}\text { Kemampuan menghafal beberapa } \\
\text { konsep dalam hidrolisis garam. }\end{array}$} & - & 15 & 13 & 20,63 & 19 & 30,16 \\
\hline & & - & 16 & 16 & 25,40 & 18 & 28,57 \\
\hline & & - & 17 & 19 & 30,16 & 17 & 26,98 \\
\hline & & - & 18 & 18 & 28,57 & 16 & 25,40 \\
\hline & \multirow{2}{*}{ Ketelitian } & 20 & - & 8 & 12,70 & 11 & 17,46 \\
\hline & & 21 & - & 8 & 12,70 & 11 & 17,46 \\
\hline & \multirow{2}{*}{ Menyimpan perolehan hasil belajar } & 22 & - & 14 & 22,22 & 9 & 14,29 \\
\hline & & 23 & - & 9 & 14,29 & 18 & 28,57 \\
\hline & $\begin{array}{l}\text { Kebiasaan belajar (pendisiplinan } \\
\text { diri) }\end{array}$ & - & 24 & 32 & 50,79 & 7 & 11,11 \\
\hline \multirow{2}{*}{$\begin{array}{l}\text { Jenis } \\
\text { Faktor }\end{array}$} & \multirow{2}{*}{ Indikator Penyebab Kesulitan } & \multicolumn{2}{|c|}{ No. Soal } & \multicolumn{2}{|c|}{ Setuju } & \multicolumn{2}{|c|}{ Tidak setuju } \\
\hline & & Positif & Negatif & $\sum \mathbf{P D}$ & $\%$ PD & $\sum$ PD & $\%$ PD \\
\hline \multirow[t]{5}{*}{ Eksternal } & \multirow{2}{*}{$\begin{array}{l}\text { Peran keluarga terhadap proses } \\
\text { pembelajaran kimia }\end{array}$} & 25 & - & 27 & 42,86 & 9 & 14,29 \\
\hline & & 26 & $\begin{array}{llll}- & \\
\end{array}$ & 32 & 50,79 & 9 & 14,29 \\
\hline & $\begin{array}{l}\text { Penjelasan dan respon guru dalam } \\
\text { proses pembelajaran. }\end{array}$ & 27 & - & 13 & 20,63 & 15 & 23,81 \\
\hline & $\begin{array}{l}\text { Sarana dan prasarana sekolah } \\
\text { dalam penunjangan proses belajar. }\end{array}$ & 28 & - & 34 & 53,97 & 9 & 14,29 \\
\hline & $\begin{array}{l}\text { Peran teman diskusi atau kelompok } \\
\text { belajar. }\end{array}$ & 29 & - & 31 & 49,21 & 10 & 15,87 \\
\hline
\end{tabular}

\section{Keterangan:}

PD

$\sum$ total responden/ PD

$=$ Siswa

$\sum$ PD pada kolom setuju (+)

$=63$

$\sum$ PD pada kolom setuju (-)

$=$ Jumlah siswa yang memilih skor 4 dan 5

= Jumlah siswa yang memilih skor 1 dan 2

$\sum$ PD pada kolom tidak setuju $(+)=$ Jumlah siswa yang memilih skor 1 dan 2

$\sum$ PD pada kolom tidak setuju $(-)=$ Jumlah siswa yang memilih skor 4 dan 5

Penyebaran angket dilakukan setelah jam pelajaran kimia (setelah mengerjakan tes konsep sukar dan kesalahan konsep) dan pengerjaannya diawasi oleh peneliti sehingga data angket memiliki kredibilitas yang tinggi dan benar-benar menggambarkan pemikiran siswa pada saat itu.

Pernyataan yang mengandung kalimat positif, dengan jumlah peserta didik yang menjawab tidak setuju dan sangat tidak setuju (skor 1 dan 2) digolongkan dalam kelompok tidak setuju, sedangkan jumlah peserta didik yang menjawab setuju dan sangat setuju (skor 4 dan 5) digolongkan dalam kelompok setuju. Pada pernyataan yang mengandung kalimat negatif, jumlah peserta didik yang menjawab tidak setuju dan sangat tidak setuju (skor 4 dan 5) digolongkan dalam kelompok tidak setuju, sedangkan jumlah peserta didik yang menjawab setuju dan sangat setuju (skor 1 dan 2) digolongkan dalam kelompok setuju. Tabel 3 menunjukkan bahwa faktor yang bersumber dari dalam diri peserta didik (internal) memiliki pengaruh yang lebih banyak terhadap kesulitan peserta didik dalam mempelajari materi hidrolisis garam dibandingkan dengan faktor yang berasal dari luar 
diri peserta didik (eksternal). Pada dasarnya penetapan faktor-faktor penyebab kesulitan belajar peserta didik yang dialami berasal dari ketidak-cocokkan jawaban peserta didik dengan pernyataan dari angket yang mewakili indikator penyebab kesulitan.

Berdasarkan Tabel 3 dapat diketahui bahwa faktor internal dengan indikator kebiasaan belajar (pendisiplinan diri) dalam mendisiplinkan diri untuk belajar kimia setiap hari memiliki persentase terbesar yaitu 50,79\% siswa memilih setuju (lebih besar dari 11,11\% siswa memilih tidak setuju). Artinya, siswa mengalami kesulitan dalam mendisiplinkan diri untuk belajar kimia setiap hari. Hasil analisis menunjukkan bahwa hal tersebut disebabkan karena tuntutan tugas pelajaran yang dibebankan kepada siswa terlalu banyak. Sehingga sebagian besar siswa seringkali hanya belajar pada saat ulangan saja. Karakteristik materi hidrolisis garam yang terdiri atas konsep-konsep serta hitungan stoikiometris menjadikan materi hidrolisis garam sulit untuk dipelajari jika hanya dilakukan sesekali saja dalam waktu yang singkat. Proses pembelajaran materi ini harus dilakukan berulang-ulang dan konsisten untuk dapat memantapkan konsep-konsep yang harus dikuasai. Kekonsistenan siswa dalam belajar menentukan tingkat pemahaman siswa. Hal inilah yang menjadikan siswa sulit untuk mendisiplinkan diri untuk tetap konsisten dalam mempelajari kimia.

\section{KESIMPULAN}

Kesimpulan penelitian ini adalah sebagai berikut:

1. Konsep sukar yang dimiliki siswa kelas XI MIA Tahun Ajaran 2017/2018 adalah konsep: (a) penentuan sifat ion dalam larutan dengan indikator menganalisis sifat kation dan anion dalam larutan berdasarkan harga $\mathrm{Ka}$ dan $\mathrm{Kb}$; (b) persamaan reaksi hidrolisis garam dengan indikator menentukan persamaan reaksi hidrolisis garam berdasarkan kekuatan asam/basa penyusunnya; (c) penentuan sifat keasaman larutan hasil hidrolisis pada reaksi hidrolisis garam dengan indikator menentukan sifat keasaman larutan garam yang anion dan atau kationnya terhidrolisis; (d) stoikiometri larutan hidrolisis garam dalam hubungannya antara massa dan $\mathrm{pH}$ larutan dengan indikator menghitung dan menentukan harga $\mathrm{pH}$ suatu larutan garam dari massanya dan sebaliknya; (e) konsep perhitungan nilai $\mathrm{Ka}, \mathrm{Kb}$, dan Kh dalam hidrolisis garam dengan indikator menghitung nilai $\mathrm{Ka}, \mathrm{Kb}$, dan $\mathrm{Kh}$ dalam hidrolisis garam.

2. Kesalahan konsep yang dialami siswa adalah pada konsep: (a) ion yang berasal dari basa lemah tidak mengalami hidrolisis sebanyak $2 \%$ siswa; (b) kation dari basa kuat dapat bereaksi dengan molekul air sebanyak 2\% siswa; (c) kekuatan basa konjugat sebanding dengan kekuatan asam sebanyak 3\% siswa; (d) kekuatan basa konjugat tidak dapat ditentukan dari harga Ka sebanyak $3 \%$ siswa; (e) sifat ion sama dengan sifat zat asalnya sebanyak 5\% siswa; (f) hidrolisis anion dari asam lemah menghasilkan ion $\mathrm{H}_{3} \mathrm{O}^{+} / \mathrm{H}^{+}$sebanyak 2\% siswa; (g) tidak mengkonversikan satuan volume larutan kedalam liter sehingga mengakibatkan perhitungan menentukan massa garam salah sebanyak 8\% siswa; (h) tidak memahami rumus mencari tetapan hidrolisis larutan garam yang berasal dari asam lemah dan basa lemah, yang seharusnya

$$
\mathrm{Kh}=\frac{\mathrm{Kw}}{\mathrm{Ka} \times \mathrm{Kb}} \text { bukan } \mathrm{Kh}=\sqrt{\frac{\mathrm{Kw}}{\mathrm{Ka} \times \mathrm{Kb}}}
$$

sehingga mengakibatkan perhitungan Kh garam salah sebanyak 3\% siswa; (i) tidak memahami rumus mencari tetapan hidrolisis larutan garam yang berasal dari asam lemah dan basa lemah, yang seharusnya

$$
\mathrm{Kh}=\frac{\mathrm{Kw}}{\mathrm{Ka} \times \mathrm{Kb}} \text { bukan } \mathrm{Kh}=\frac{\mathrm{Ka} \times \mathrm{Kb}}{\mathrm{Kw}}
$$

sehingga mengakibatkan perhitungan Kh garam salah sebanyak $2 \%$ siswa. 
3. Hasil analisis penelitian menunjukkan bahwa faktor-faktor terbesar penyebab kesulitan siswa dalam mempelajari materi hidrolisis garam adalah faktor internal, sedangkan faktor eksternal hanya sedikit sekali pengaruhnya. Faktor-faktor internal tersebut antara lain (1) kemampuan dalam hitungan (operasi matematis) sebesar 27,51\%. (2) Kemampuan menentukan dan menggunakan rumus kimia sebesar 30,16\%. (3) Kemampuan menghafal beberapa konsep dalam hidrolisis garam sebesar 29,37\%. (4) Tingkat ketelitian sebesar 17,46\%. (5) Menyimpan perolehan hasil belajar sebesar 32\%. (6) Kebiasaan belajar (pendisiplinan diri) sebesar 50,79\%. Sedangkan faktor-faktor penyebab kesulitan siswa dalam mempelajari materi hidrolisis garam yang bersumber dari luar diri siswa (eksternal) yaitu penjelasan dan respon guru dalam proses pengajaran sebesar $23,81 \%$.

Berdasarkan hasil yang diperoleh melalui penelitian ini, saran yang dapat diusulkan yaitu proses pembelajaran konsep-konsep hidrolisis garam harus dilakukan secara kontinyu dan berkesinambungan. Artinya, dalam penyampaian materi hidrolisis garam harus dikaitkan dengan materi atau konsep dasar prasyaratnya, sehingga siswa benar-benar memperoleh pemahaman yang utuh dan tidak sebatas menghafalkan teori atau rumus-rumus kimia. Mengingat karakteristik ilmu kimia yang berkesinambungan sehingga penekanan pada konsep-konsep prasyarat lebih diperhatikan. Hal tersebut dimaksudkan agar tidak terjadi konsep sukar dan kesalahan konsep pada siswa. Konsep sukar dan kesalahan konsep yang terjadi pada siswa memerlukan penegasan dan perhatian dalam proses pembelajaran, sehingga siswa tidak mengalami kesulitan dalam memahami konsep-konsep pada setiap materi. Hasil penelitian ini dapat digunakan guru mata pelajaran kimia untuk merancang pembelajaran menggunakan strategi peta konsep pada setiap materi yang akan diajarkan untuk mengetahui konsep-konsep dasar yang harus dikuasai oleh siswa. Hal tersebut dimaksudkan agar siswa memiliki gambaran materi yang akan diterima dan dapat menggali hasil belajar yang tersimpan.

\section{DAFTAR PUSTAKA}

Ansori, Yusrotul Nisa. 2015. Pengembangan Modul Larutan Buffer Berdasarkan Persepsi Konsep Sukardan Kesalahan Konsep dengan Daur Belajar 3 Fase untuk. Mata Kuliah Kimia Dasar 2. Tesis tidak diterbitkan. Malang: Program Studi Pendidikan Kimia FMIPA UM.

Effendy. 2002. Upaya untuk Mengurangi Kesalahan Konsep pada Pengajaran Kimia dengan

Menggunakan Strategi Konflik Kognitif. Media Komunikasi Kimia, 2(6): 1-20

Irawati, R. K. 2010. Hubungan Pemahaman Konsep Asam-Basa Arrehenius dan Bronsted-Lowry dengan Konsep Hidrolisis Garam Siswa Kelas XI SMA Negeri 1 Lawang Tabun Ajaran 2009/2010. Skripsi tidak diterbitkan. Malang: Program Studi Pendidikan Kimia FMIPA UM.

Kean, E. \& Middlecamp, C. 1985. Panduan Belajar Kimia Dasar. Jakarta: PT Gramedia.

Quliyah. B. 2012. Identifikasi Persepsi Konsep Sukan dan Kesalahan Konsep Hidrolisis pada Siswa Kelas XI SMA Negeri 5 Malang. Skripsi tidak diterbitkan. Malang: Program Studi Pendidikan Kimia FMIPA UM.

Sastrawijaya, T. 1988. Proses Belajar Mengajar Kimia. Jakarta: Depdikbud Dirjen Dikti PPLPTK.

Seçken, N dan Alşan, E. U. 2011. The Effectof Constructivist Approach on Student's Understanding of The Concepts Related to Hydrolysis. Procedia Social and Behavioral Sciences. No. 15: 235-240.

Wiyono, G. P. 2011. Identifikasi Konsep Sukar dan Kesalahan Konsep Asam-Basa Bronsted-Lowry pada Siswa Kelas XI SMA Negeri 1 Malang Tahun Ajaran 2010/2011. Skripsi tidak diterbitkan. Malang: Program Studi Pendidikan Kimia FMIPA UM. 